\title{
Existence and Evolution of Business Groups in Emerging Economies: A Selective Review of the Literature
}

\author{
By, Rupambika Bharati*
}

\begin{abstract}
Business Groups and their ubiquitous presence in emerging economies affect the broad patterns of economic performance. The study of such hybrid organizational form has been relevant to various domains such as industrial organization, corporate finance, strategic management, economics and sociology etc. This paper is an attempt to first understand the reason for their dominant presence in emerging markets and then proceeds to review the literature based on the dominant research perspectives of the existing scholarly work.
\end{abstract}

Key Words: Business Groups, Corporate Strategies, Diversification, Emerging Economy

\begin{abstract}
*Amrita School of Business Coimbatore; Amrita Vishwavidyapeetham, Ettimadai Coimbatore641112, India; rupambikabh@gmail.com
\end{abstract}

\section{Introduction}

Dominance of business groups is a characteristic of emerging economies. Business groups go by different names in different countries (e.g., chaebol in South Korea, grupos in Latin America, business holdings in Turkey and business houses in India), yet they share some broad attributes. The member firms do remain legally independent, but there exists a series of economic and social ties, which unites them together. This enables the group members to coordinate their actions in product and factor markets (Khanna \& Rivkin, 2001). The group affiliates or members operate in businesses which are related, linked or unrelated. This chapter seeks to develop an overall understanding of business groups, the theoretical explanations for their presence and emergence in emerging markets and reviews the existing literature focused on groups.

\section{Organizational Form of Business Groups}

Based on the literature, we can define a business group as a collection of formally separate and independent affiliates under common managerial and economic control. There are two distinct characteristics that can be considered to distinguish between business groups from other business organizations (Yiu et al., 2007). The first characteristic is presence of social relations in addition to economic connections; this is one factor that differentiates business groups from multinational corporations or holding companies. The second characteristic is the presence of a core entity having common financial and administrative control. The core entity is like the concept of central actor in social network theory. This core entity can be the founding member or the founding family,a foundation, a financial investor such as a bank, a financial institution or a state-backed enterprise. This makes the group a confederation where exists a powerful parent or 'core' company surrounded by affiliates. The parent company usually holds a dominant position and control over resources and information. Vertical control over the affiliate in terms of ownership and social coordination determines the relationship between a core firm and an affiliate (Lorenzoni \& Baden- 
Fuller, 1995).

\section{Pyramidal Ownership of Business Groups}

The ownership of business groups has a pyramidal arrangement (Almeida \& Wolfenzon, 2006) with controlling shareholders, which could be a family or state (La Porta et al., 1999). The presence of a 'core' (could be a family or state or a foundation) which exerts power and control is central in organizing the business group as a pyramid. The 'core' controls a firm which controls another firm and this firm controls another firm, and so on and so forth. A holding company at the top owns shares in subsidiaries, and these subsidiaries have subsidiaries of their own. This arrangement helps in securing control and extracting private benefits. The traditional view of separation of cash flow from voting rights as a reason does not fully explain the pyramidal arrangement. A pyramidal arrangement is not the only way to achieve the separation of cash flow from voting rights. This separation can be achieved using dual class shares in the absence of restrictions on them. The literature suggests pyramids are more common than dual-class shares (La Porta et al., 1999).

\section{Business Groups in different Countries}

Business groups have country specific characteristics

- Chinese Business Group: Chinese business groups have ties with the state and not with any particular family (Keister, 1998).

- Japanese Keiretsu: A Japanese Keiretsu is characterized by the presence of close ties with the group's main banks (Akoki, 1984).

- Korean Chaebol: The Korean Chaebols are strongly linked with state agencies and depend on the priorities of politicians and policymakers (Jones \& Sakong, 1980).

- Taiwanese Business Group: Taiwanese Business groups are small and loosely integrated entities and do not have a strong authoritarian style (Fields, 1995).

\section{Features of Indian Groups}

The common feature of an Indian Business Group is the promoter holding the top managerial position along with the presence of family members and friends employed at such positions. The group is controlled by interpersonal associations (Gadgil, 1951). Group affiliates are independent and legal entities and are not linked to any group bank. Founding members and their families control groups by common board members, directorial interlocks and equity cross holdings (Khanna \& Palepu, 1999a).

\section{Existence of Business Groups in Emerging Economies}

According to Guillen (2000), there are three different ways to study business groups. The institutional void thesis and transaction cost theory suggest the business groups exist in emerging economies because they substitute for the missing institutions and mediate relationship-based transaction which results in a lower cost. This approach is followed by economists. Economic sociology emphasizes on non-economic reasons based on social and cultural patterns (Granovetter, 2005). Political economics examines the relationship groups share with the political and bureaucratic apparatus of country. This examination leads to the proposition of rent seeking behavior exhibited by groups, when they use political connection to frame policies favorable for them. 
The Resource Based View: Business Groups

The resource-based view implies that competitive advantage of a firm is result of implementation of a value creating strategy, which is not implemented by any competitor (Barney, 1991). Guillen (2000) argues that emerging economies with a scenario of asymmetric trade and investment environments, allow a few entrepreneurs and firms to develop the capability of combining therequired foreign and domestic resources. Combination of foreign and domestic resources forms inimitable capabilities which enable firms for repeated industry entries and diversification.

\section{Major Theoretical Perspectives on Business Group Research}

Four theoretical perspectives have been used by scholars to examine business groups: agency theory, transaction cost theory, a political economy perspective and a relational perspective.

\section{Agency Theory}

As per agency theory business groups are considered a collection of relationships between different agents i.e., between controlling and minority shareholders. The pyramidal form of ownership creates an arrangement in which even with a small fraction of ownership, the holding company controls a large amount of assets. This leads to 'tunneling' of resources by the controlling shareholders. This leads to expropriation of wealth of the minority shareholders by the core. This is the principal-principal agency problem (Dharwadkar et al., 2000). Agency theory has been helpful in examining the ownership structure of business groups. There exists a core entity such as a family in groups which exerts power and control over use of resources and management. The controlling shareholder hires managers who act on their behalf and family members hold key positions. Along with the agency problem between the owners and management exists a secondary agency problem between controlling and minority shareholders (Dharwadkar et al., 2000).

\section{Transaction Cost Theory}

The most popular theory for the study of business groups is the transaction cost theory. As per this theory, following Coase (1937) and Williamson (1975, 1981b, 1985), markets and firms are two governance and coordinating mechanisms for the exchange of goods and services. Managers must choose the best organizational arrangement to achieve lower transaction costs (Teece, 1981). Efficient market condition is improved by better market information, enforcement mechanism, external monitoring, and better corporate governance. With poor market institutions, the ease of business is improved through power and authority exerted by organizational hierarchies. The argument proposed by Khanna and Palepu (1997) is that transaction costs are high in emerging economies due to the presence of institutional voids. The high transaction costs are reduced by the organizational arrangement of business groups. The internal markets present in business groups is well coordinated by group management and serves as a substitute for inefficient institutions. They coordinate and allocate the exchange of resources, information, and services. This makes "Transaction Cost" theory a powerful theoretical perspective to understand the structure and strategy of business groups.

\section{Political Economy Perspective}

Political economy perspective argues that business groups have been used as an instrument for 
industrial development by the state (Fisman \& Khanna, 2004). This school suggests that political and government involvement is one of the principal factors in the formation of business groups in emerging economies. The institutional transition process in emerging economies has been facilitated by inducing the formation of business groups by the respective governments (Yiu et al., 2005). The state can either help in the form of direct investment which leads to the formation of large business groups in specific industries or may provide provision of subsidies, licences, land, technology and information to develop business groups that are considered strategic by the state.

Based on this theoretical conceptualization, two sources of resources and capabilities for business groups are recognized. Many business groups in emerging economies have their origins in former state-owned enterprises and have what is known as 'endowed resources'. This is the administrative and management history which are integral to group development. After the formation of business groups, they acquire different resources and develop capabilities suitable for their strategies for gaining competitiveness (Yiu et al., 2005). This second type of resources is called acquired resources.

\section{Relational Perspective}

The relational perspective proposes that a society's traditions and cultural norms evolve into business groups. It argues that the social institutions which form the general patterns of trust and cooperation influence economic exchanges too. Granovetter (1994) argues that it is not the economic rationale of 'minimum efficient scale' (Chandler, 1990) and 'minimum transaction costs' (Coase, 1937; Williamson, 1975, 1985) that determines economic exchanges. Social and cultural factors such as power and prestige that exist in relationships also influence economic exchange.

\section{Overview of the External Contextual Factors}

Theoretical perspectives used to examine business groups highlight contextual factors which impact groups (Yiu et al., 2007). The four contextual factors are: monitoring and control systems (agency theory), external market conditions (transaction cost theory), political factors (political economy perspective) and cultural and social patterns (relational perspective). Each perspective helps in understanding the external context that influences the internal functioning.

\section{Internal Mechanisms}

Business groups adapt themselves to mitigate the inconsistencies and complexities in various institutional environments. The attributes of these adaptations can be studied along two dimensions (Yiu et al., 2007). The first dimension examines the horizontal connections among group affiliates. The second dimension highlights the vertical linkage which is primarily ownership and control of resources within a group. Various internal mechanisms are followed in these two dimensions.

\section{Horizontal Connectedness}

Horizontal connectedness explains the linkages among affiliates in a business group. Though affiliates are legally independent entities, there are different internal mechanisms for horizontal connection among them. 


\section{Internal Transaction Mechanism}

Due to the presence of institutional voids affiliates trade through internal markets in business groups for resources, capital, labor and products. There are many advantages of such internal transactions, which include better information to base decisions of resource allocation among affiliates (Chang \& Hong, 2000; Gertner et al., 1994; Guillen, 2000; Khanna \& Palepu, 2000a). Political and economic factors also impact internal transaction mechanisms. The state's policy provisions for industry specific resources like technology or generic resources as capital increases the possibility of internal transactions of either specific or generic resources between group affiliates. Fisman and Khanna (2004) report that when the state imposes an increase in control over certain industries, internal transactions are aimed at cross subsidization not economic efficiency.

\section{Cross-shareholding}

Cross-shareholding is an ownership situation when individual firms own shares among each other. Cross-shareholding facilitates exchange of information and resources, enables firms to exert control and cross-monitor each other (Lincoln et al., 1996). It binds firms by equity ties into a horizontal network which mitigates the risk of takeovers and competition (Chang, 2003a; Lincoln et al., 1996).

\section{Interlocking Directorates}

A way to achieve non-ownership control is by inter-organization directorial interlocks. They impact corporate behaviors like monitoring, coordination, collusion, career advancement and social ties (Pettigrew, 1992; Stearns \& Mizruchi, 1986; Windolf \& Beyer, 1996). Haunschild and Beckman (1998) found that directorial interlocks facilitate information flow which influence corporate strategy.

\section{Social Ties}

Social ties are also a form of non-ownership governance and control tool. Social ties are not based on low cost efficiency but on the basis on the thought that relations are stable and trustworthy and can help in risk avoidance. It helps in achieving mutual interests and creates a community system to share information, resources and coordinate activities among firms (Granovetter, 1994, 2005; Poppo \& Zenger, 2002).

\section{Vertical Linkages}

Vertical structure functions as the second internal mechanism with its command-and-control chain from the dominant core to the individual firm. There is the presence of a powerful entity which

holds most shares unlike other organizational forms where the ownership of shares is dispersed. This is as mentioned before is the powerful 'core'.

\section{Core}

This could be the founder or family that founded a business group which holds a dominant role in management. The core holds authority over affiliate firms through pyramidal ownership structure or cross-ownership. This pyramidal organization has a structure in which each unit holds stocks in 
units at the lower level of the business group. A holding company owned by the core is at the top of the pyramid. Such an arrangement results in majority control through a smaller investment by the core. Dual class shares could also be used to obtain control where the core owns shares with higher voting rights. In Italy, Switzerland and Sweden dual class shares are used by $41 \%, 51 \%$ and $66 \%$ of firms respectively (Faccio \& Lang, 2002).

\section{Control}

The core exerts its control in three ways over the management of a business group. The first is when strategic/managerial positions are taken over by family members or friends, which integrates management and ownership. The second way is to form an ownership pyramid to extend control over individual firms. The third way is control over strategic resources such as technology, production and distribution channels which the core uses to control and influence individual firm decisions (Yiu et al., 2007).

\section{Evolution and Transformation of Business Groups: Case of India}

Two features are notable to characterize emerging economies: (1) though the development started late but was speedy, facilitated by government policies to usher liberalization and (2) movement towards a free market system (Arnold \& Quelch, 1998). The mutual and reciprocal influence of institutional environments and organizational action explains the evolution of business groups in emerging economies (Carney \& Gedajlovic, 2002). Organizational forms and practices have theirorigins in the social and political circumstances (Keiser, 1989).

In India, the task of promoting industries after World War I was carried out by the merchant groups(Singhal and Tagore, 2002). They continued participating in industrial and manufacturing activities even after the war and eventually transformed into powerful business groups after India's independence in 1947 (Kedia et al., 2006). Carney and Gedajlovic (2002) project end of Cold War, emergence of Japan and commercialization of knowledge intensive products to be the exogenous forces that impacted firms based in Southeast Asia. They are concurrent with the fact that Business groups in this region too have colonial origins.

The evolution of Indian business groups can be studied in two sections: (1) pre-reform era and (2)post-reform era. The pre-reform era was associated with a centrally planned economy and a high level of government interference in the private sector (Khandwalla, 2002).

During the pre-reform era, there was the existence of Foreign Exchange Regulation Act (1973), Indian Monopolies and Restrictive Trade Practices (MRTP, 1969) Act and Industrial Licensing Policy Inquiry Committee (1969) (Majumdar, 2004). These statutory mechanisms increased government control and created entry barriers for foreign investors. This period is known as 'License Raj' which means license regime (Majumdar, 2004). This resulted in bureaucratic hurdles and distortion in incentives which discouraged entrepreneurship, and retarded economic and business activity. With its excessive import licensing, there was no foreign competition and the markets belonged to the sellers (Das, 2001). This led to many groups lining up for licenses in almost all sectors and chose to follow the path of unrelated diversification (Khanna \& Palepu, 1997).

Several economic reforms were introduced in 1991. The erstwhile Controller of Capital 
Issues (CCI) was closed, and a regulatory body to improve the functioning of capital markets known as Securities and Exchange Board of India (SEBI) was created. Stock market deregulation formed anintegral component of the financial sector reforms program. Companies became free to price their primary issues in accordance with market forces after the repeal of the Controller of Capital Issues Act (CCI Act) of 1947 in May 1992. The Securities and Exchange Board of India (SEBI) Act of 1992 gave the SEBI regulatory powers to regulate the securities market.

Entry of foreign investors was allowed and substantial clarifications regarding regulations were also made. Salient features included the removal of floors and ceilings on investments. Implementation of the new industrial policy entailed most sectors were liberalized (except defense related industries). Many import restrictions and quotas were gone; tariff barriers were also brought down. Hence India saw the removal of the MRTP Act and opening of its economy, leading to an improvement in the state of its institutions governing markets post-liberalization.

The business groups were exposed to a different business environment with increased competition, which led to increased diversification for unregulated growth (Kedia et al., 2006). Khandwalla (2002) reports that in this new business landscape, while some firms focused on their core competencies, others pursued a vigorous diversification strategy. This period witnessed Mergers and Acquisitions by Indian business groups and few groups started venturing overseas too. The general path was towards an increased related diversification followed by business groups (Kediaet al., 2006).

\section{Dominant Research Lenses on Business Groups}

Scholars from various domains such as industrial organization, corporate finance, strategic management, economics and sociology etc., have tried to use diverse lenses to analyze and understand business groups (Khanna \&Yafeh, 2005b). In this section, I have tried to analyze the existing literature based on the different research perspectives.

\section{Groups, Diversification and Performance}

Corporate focus and diversification have been an important theme of research in the existing literature. There continues to be dispute over whether diversification is value enhancing or value destroying for firms. Several studies (Lang \& Stulz, 1994; Burger \& Ofek, 1995; Servaes, 1996; Lins \& Servaes, 1999) have stated that corporate diversification has not benefited the value of firms in the developed countries (US, UK., Germany and Japan).

Diversification, if driven by managerial objectives such as "empire building" or "risk aversion" could be harmful. There is evidence in the literature which suggests that, diversification is associated with a loss of firm value - a phenomenon called "diversification discount" in developed economies, while the discount is found to be lower in economies where the markets are less developed. Fauver et al. (2003) state that diversification discount is a feature of developed markets and institutions whereas in less developed economies, there is no discount but sometimes a premium for corporate diversification. It has been reported by Claessens et al.(1999), by using both stock market and accounting variables found that there exists a diversification premium in less developed economies in East Asia (Indonesia, Phillipines and Thailand), and a diversification discount in the richer and more developed economies in the region (Hong Kong and Taiwan).

Khanna and Palepu (2000a) have stated that diversification is valuable. In their study, using data from 1993, they have examined the performance of firms belonging to diversified Indian business 
groups relative to non-affiliated firms. They state that with group diversification firm performance initially declines but, subsequently improves once group diversification crosses a certain threshold level. They have suggested that the most diversified business groups replicate the functions of institutions and intermediaries that are either absent or inadequate in emerging economies. Scale and scope of their operations enable business groups to cope with inadequacies compared to smaller firms because of the spread of the fixed costs associated with performing the functions. Kakani (2000) finds that shareholder value creation was negatively related to the product diversification level of business houses. Khanna and Palepu (2000b) have reported a declining group premium associated with economic reform in Chile. Lee et al. (2001) have found that in early 1990's firms affiliated to Korean Chaebols used to be traded at premium which turned into a discount around 1994.

George and Kabir (2012) have studied how heterogeneous features among business groups influence the diversification-firm performance relationship. The affiliated firms mitigate theunderperformance from corporate diversification. They find no evidence for the moderatingeffect of business group diversity.

\section{Diversification and Performance: Group-affiliated versus Non-affiliated Firms}

The performance comparison of group-affiliated and non-affiliated firms dates to Caves and Uekusa (1976)'s study of Japanese business groups. Chang and Choi (1988) have found that the top four Korean Chaebols outdo other firms of the economy including smaller chaebols and nonaffiliated firms. Chang and Choi (1988) attribute the advantage of group firms to the relative efficiency that stems from lower transaction costs and effective management.

Many studies in contrast with Chang and Choi (1988), report that in Korea, group affiliated firms perform relatively poor in the 1990s (Khanna \& Yafeh, 2005b). Many scholars relate inadequate corporate governance to lower profits of affiliated firms. Shin and Park (2003) and Lee and Lee (2002) claim that group affiliated Korean firms over-invest compared to the profitability. These studies help us in drawing a conclusion that the advantage that firms belonging to groups enjoyedgot eroded during the 1990 s.

Khanna and Palepu (2000a) report a nonlinear relationship between diversification and profit. In their study, they examined the performance of firms belonging to diversified Indian business groups relative to standalone firms. They found that firm performance improves once group diversification crosses a certain threshold. Lensink and Van der Molen (2010) have tried to studythe relationship between affiliation and diversification as proposed by Khanna and Palepu (2000a), by conducting their study in the period between 1996 and 2001. Lensink and Van der Molen(2010) believe group affiliation helps firms that suffer financial constraints. Khanna and Palepu (2000b) report better performance associated with high levels of group diversification in Chile. The finding is interpreted that groups in emerging markets replicate functions for missing and absent institutions.

Khanna and Rivkin (2001) studied the effects of group affiliation on firm profitability that is on whether affiliation could either enhance or destroy firm profitability. They tested these hypotheses in 14 emerging markets: Argentina, Brazil, Chile, India, Indonesia, Israel, Mexico, Peru, the Philippines, South Africa, South Korea, Taiwan, Thailand and Turkey. The results reveal that 
group affiliates have higher profitability than non-affiliated firms in India, Indonesia, and Taiwan. There is weaker evidence for group affiliates having higher profitability in Israel, South Africa, and Peru. In Argentina, group affiliates perform worse than non-affiliates.

Fisman and Khanna (2004) studied plant location decisions in India with regard to profitability. Their study shows that group-affiliates are more likely to be profitable if located in less developedstates than non-affiliated firms. These results were stronger for the recent location decisions. Castellacci (2015) has compared the innovativeness of affiliated and standalone firms and investigated how institutional factors and country specificity affect the group-innovation relationship in Latin America. The main conclusion of his empirical study has been that group affiliated firms are more innovative than standalone firms. The second conclusion is of much interest as it refers to the empirical test of two contrasting theses; the institutional void thesis and the organizational resilience thesis. His study provides stronger support for the latter than the former view. Superior innovation performance of affiliated firms is stronger for national economies with more efficient institutions, which is in line with the organizational resilience thesis.

\section{Propping and Tunneling}

Kali and Sarkar (2005) in their paper found that business group affiliation generates higher market valuation but diversification is not the reason for these benefits. They found that the propping through profit transfers among firms within a group and directorial interlocks lead to higher market valuation of affiliated firms. In firms where, controlling shareholders have above median cash flow rights, directorial interlocks are the primary source of the group effect. Propping seems to be thesource of group affiliation benefit for firms where below median cash flow rights are with the controlling shareholders (Kali and Sarkar, 2005).

Joh (2003) finds that non-affiliated firms perform better than large chaebol affiliated firms and this is due to expropriation of firm resources by controlling shareholders (tunneling). Tunneling existsin several emerging markets, including India (Bertrand et al., 2001; Cheung et al., 2006). Friedmanet al. (2003) argue that controlling shareholders use private resources to provide support to firms that are in trouble, i.e., prop up firms. Friedman et al. (2003) suggest that propping explains that firms rely on debt finance in emerging economies.

In a business group, independently traded firms are controlled by a single shareholder or a family or a trust having significant cash flow rights in only a few of them. Strong incentives to expropriate are created by this discrepancy in cash flow rights between different firms they control. There is apropensity for the controlling shareholder to transfer, or tunnel, profits across firms. Transfer of resources is possible in many ways: loans, transfer prices, or sale of assets to each other to list a few. If continued, tunneling may have serious consequences. Financial development and equity market growth of a firm are hindered if the returns to an outside shareholder are reduced (Bertrand et al., 2002). The anecdote stated by Bertrand et al. (2002) is about a firm called Kalyani Steels. More than two-thirds of its net worth was invested in other companies in its group. Bertrand et al.(2002) find higher q-ratios and greater profitability to be associated with firms where the controlling shareholder has higher cash flow rights. This is informative but not a test of tunneling since differences in pre-existing efficiency or any other factor may determine higher q-ratios and higher profitability.

Manipulation of non-operating components of profits is a way in which Indian business 
groups tend to tunnel. Operating profits alone are not expropriated. Bertrand et al. (2002) suggest the presence of tunneling. Their findings show that firms with market-to-book ratio firms are found to be more sensitive to both their own shocks and shocks to the other firms in their group. Firms affiliated to groups having high market-to-book ratio are also more sensitive to their own shock, but are not significantly more sensitive to the group's shock.

Gopalan et al. (2007) found that cash is transferred by intra-group loans across group firms to support financially weaker firms. They indicate that intra-group loans are significant and are important among Indian business groups. The recipients are those firms which underperform as per both market and operating performance. They do not support the existence of tunneling in Indian groups.

George and Kabir (2008) have documented effect of profit redistribution within a business group. High performing group affiliated firms experience a decline in performance. They have also investigated whether there exists a relationship between profit redistribution effect and the extent of control exerted by the controlling shareholders and group size. Their empirical study shows that the extent of profit redistribution exists in firms belong to the largest business groups with high levels of control.

\section{Relations between Business Groups and Governments}

Strong links with the political and bureaucratic apparatus of a country helps business groups in extracting benefits from the state (Khanna \& Palepu, 1997), explained by the rent seeking behavior. The rent seeking hypothesis asserts that business groups extract gains using their influence over government policies and actions. (Khanna \& Palepu, 2005).

The political economy literature supports the idea that government policies influence the emergence and existence of business group. In Japan, the privatization policy of the government helped the emergence of pre-war zaibatsu groups, there existed close ties between the then government and the pre-war zaibatsus (Hadley, 1970). The Korean chaebols have close ties with the government (Clifford, 1994; Kim, 1997; Chang, 2003a). Gomez and Jomo (1999) believe, in Malaysia, Prime Minister Mahathir's government helped certain ethnic Malay owned business groups. Keister (1998) has described that in China, formation of business groups was encouraged by the government which protected them from foreign competition as well.

There is econometric evidence for political connections (Fisman, 2001) enjoyed by business groups during the Suharto regime in Indonesia. In India, during "License Raj" certain business groups were favored (Khanna \& Palepu, 2005).

Xavier et al. (2014) have studied how institutional environments affect the Business Group performance in Brazil. They have suggested that there is a significant effect of institutional environments on performance and is moderated by political connections, assessed by the presence of local or federal government as a minor shareholder of the Business Group.

\section{Groups and Market Power}

Khanna (2000) has the opinion that groups by substituting for missing market institutions are simultaneously welfare enhancing, and by expropriating minority shareholders are welfare reducing agents. There are theoretical explanations for business groups exerting considerable market power. Creating barriers for new entrants by using their close ties with the 
government is one of the unproductive economic activities. Khanna and Yafeh (2005b) report a scarce evidence for restricted competition in this regard. Khanna (2000) has the view that groups are simultaneously welfare enhancing, since groups make up for market failures, and welfare reducing since they expropriate minority shareholders. As reported by Khanna and Palepu (2005), groups diversify into industries in which even the government refuses to. By diversifying into unrelated industries, they benefit the society.

\section{Groups as Social Networks}

Economic sociology literature views business groups as networks. Sociologists emphasize on social ties based on ethnicity, caste, religion, family, language, and region. The sociology literature shifts the focus to other forms that the group may take. Granovetter (2005) in his survey of economic sociology literature on business groups suggests economic efficiency not to be the only reason explaining their existence. He argues that the variation in the structure of business groups across different countries reflects social, cultural, and institutional ties go beyond economics. In India, the Gujarati, Marwari and the Parsi communities are the dominant business ethnic communities. These ethnic networks are substitutes for institutional voids, as they relied on their own internal sources and members for information and effective contractual enforcement (Khanna \& Palepu, 2005). Prominent business groups have shown willingness to help spawn new members from the same ethnic community to start businesses, sometimes even to compete with their own businesses. Several groups emerged from the Birla group (e.g., Khaitan and Kejriwal) and continue to exist (Piramal, 1998).

\section{Theoretical Development}

The institutional evolution and transition of emerging economies ushered the need for understanding the theoretical development, which explains business group performance in a postreform era in an emerging economy. Traditionally, market imperfections characterize emerging economies (Khanna \& Palepu., 2005, Peng \& Heath., 1996). In this scenario, transaction cost tends to be high due to weak enforcement of contracts and absence of intermediaries for information, capital, labor and enforcement requirements, which obstruct business operations (Khanna \& Rivkin, 2001). Business groups with their internal markets make up for the missing institutions and reduce high transaction cost arising due to market imperfections (Khanna \& Palepu, 1997). Group affiliation comes with costs too which could arise due to conflict of interests resulting in misallocation of capital and subsidization of unprofitable ventures (Zattoni et al., 2009). Inefficient compensation and suboptimal decisions made at the head office are also sources of costs.

The development of market institutions improves business competition and removes obstacles to business operations and resource mobility. The value generated by the internal markets of business groups declines overtime as institutions develop in emerging economies (Khanna \& Palepu, 2000b). However, the institutions remain relatively undeveloped in the early phase of transition. As institutions develop, market-based competition gets institutionalized for managing transactions. Cross-border trade and investment increases and foreign multinationals start exerting competitive pressures (Lee et al., 2008). Presence of a more regulated, open and transparent capital market and more competitive labor and product market favor a rule-based transaction instead of a relationship based transaction (Leblebici et al., 1991). Thus, the group's affiliation no longer stays cost effective in terms of overcoming market imperfections (Guillen, 2000). The value creating

potential of business groups is diminished by the evolution of institutional environment. A move 
from relationship-based transaction to a rule-based transaction happens at a slower pace in business groups due to deep embedded old institutional and cultural workings (Oliver, 1992; Peng, 2003; Zattoni et al., 2009). The recent thesis of organizational resilience (Castellacci, 2015) in contrast to the institutional void thesis is of great interest. This gives a new paradigm for future research as most of the extant literature has been based on the institutional void thesis which is rooted in the transaction cost theory as proposed by Coase (1937) and Williamson (1975).

\section{Discussion and Conclusion}

In this article, we have attempted to understand business groups in an emerging market context and have reviewed scholarly work focused on business groups. Business groups continue to be a fascinating topic for research for many scholars. There are diverse perspectives through which they have been studied. Theoretical perspectives have helped researchers in having a focused evaluation of a particular dimension of the environment. Internal mechanisms are then used to form adaptive responses to various environmental factors. Whether diversification is value enhancing or value destroying and does group affiliation improve firm performance have been questions that many empirical studies have tried to answer. Propping and tunneling arising because of the presence of internal capital markets leading to shareholder expropriation of firm resources (tunneling) by controlling shareholders is a well-researched theme. The political economics literature views the rent seeking behavior and relations between the groups and the political apparatus of the state to be an important area for inquiry. Sociology literature emphasis on the social ties based on family, caste, religion, language, ethnicity, and region.

There exists a contradiction over whether diversification is value destroying or value enhancing for firms. This calls for an examination of this relationship with context sensitivity. Researchers have recently opined that this relationship is dynamic, and the environment context is important to it. Macroeconomic environments and institutional development should be considered while examining the impact of diversification on performance. Many scholars have the opinion that though there is no dearth of data, there is a need for novel ways of interpretation and analysis (Khanna \& Yafeh, 2005b) required for future research.

\section{References:}

Almeida, H. V., \& Wolfenzon, D. (2006). A theory of pyramidal ownership and family business groups. Journal of Finance, 61(6), 2637-2680.

Aoki, M. (1984). The economic analysis of the Japanese firm. New York: Elsevier Science Pub. Co.

Arnold, D. J., \& Quelch, J. A. (1998). New strategies in emerging markets. MIT Sloan Management Review, 40(1), 7.

Barney, J. (1991). Firm resources and sustained competitive advantage. Journal of Management, 17(1), 99-120.

Berger, P. G., \& Ofek, E. (1995). Diversification's effect on firm value. Journal of Financial Economics, 37(1), 39-65.

Bertrand, M., Mehta, P., \& Mullainathan, S. (2002). Ferreting and tunneling: An application to Indian business groups, Quarterly Journal of Economics, 117(1), 121-148. 
Castellacci, F. (2015). Institutional voids or organizational resilience? Business groups, innovation, and market development in Latin America. World Development, 70, 43-58.

Carney, M., \& Gedajlovic, E. (2002). The co-evolution of institutional environments and organizational strategies: The rise of family business groups in the ASEAN region. Organization Studies, 23(1), 1-29.

Caves, R. E., \& Uekusa, M. (1976). Industrial organization in Japan. Washington, DC: Brookings Institution.

Chang, S. J. (2003). Financial crisis and transformation of Korean business groups: The rise and fall of chaebols. Cambridge: Cambridge University Press.

Chang, S. J., \& Hong, J. (2000). Economic performance of group-affiliated companies in Korea: Intragroup resource sharing and internal business transactions. Academy of Management Journal, 43(3), 429-448.

Chang, S. J., \& Choi, U. (1988). Strategy, structure and performance of Korean business groups: A transactions cost approach. Journal of Industrial Economics,37(2), 141-158.

Cheung, Y. L., Rau, P. R., \& Stouraitis, A. (2006). Tunneling, propping, and expropriation: evidence from connected party transactions in Hong Kong. Journal of Financial Economics, 82(2), 343-386.

Claessens, S., Djankov, S., Fan, J. P., \& Lang, L. H. (1999). Corporate diversification in East Asia: The role of ultimate ownership and group affiliation. Washington, DC: World Bank.

Claessens, S., Djankov, S., \& Lang, L. H. (2000). The separation of ownership and control in East Asian corporations. Journal of Financial Economics, 58(1), 81-112.

Claessens, S., \& Laeven, L. (2003). Financial development, property rights, and growth. Journal of Finance, 58(6), 2401-2436.

Clifford, M. L. (1994). Troubled tiger: Businessmen, bureaucrats, and generals in South Korea, ME Sharpe. Inc.(Armonk, NY).

Coase, R. H. (1937). The nature of the firm. Economica, 4(16), 386-405.

Das, S. (2001). The Nehru years in Indian politics. Edinburgh Papers in South Asian Studies, 16, $1-35$.

Dharwadkar, B., George, G., \& Brandes, P. (2000). Privatization in emerging economies: An agency theory perspective. Academy of Management Review, 25(3), 650-669.

Encarnation, D. J. (1989). Dislodging multinationals: India's strategy in comparative perspective. Cornell University Press.

Faccio, M., \& Lang, L. H. (2002). The ultimate ownership of Western European corporations. Journal of Financial Economics, 65(3), 365-395.

Fauver, L., Houston, J., \& Naranjo, A. (2003). Capital market development, international integration, legal systems, and the value of corporate diversification: A cross-country analysis. Journal of Financial and Quantitative Analysis, 38(01), 135-158. 
Fields, K. J. (1995). Enterprise and the State in Korea and Taiwan, Ithaca, New York: Cornell University Press.

Fisman, R. (2001). Estimating the value of political connections. American Economic Review, 91(4), 1095-1102.

Fisman, R., \& Khanna, T. (2004). Facilitating development: The role of business groups. World Development, 32(4), 609-628.

Friedman, E., Johnson, S., \& Mitton, T. (2003). Propping and tunneling. Journal of Comparative Economics, 31(4), 732-750.

Gadgil, D. R. (1951). Notes on the rise of Business Communities in India; Gokhale Institute of Politics and Economics: Poona.

George, R., \& Kabir, R. (2008). Business groups and profit redistribution: A boon or bane for firms? Journal of Business Research, 61(9), 1004-1014.

George, R., \& Kabir, R. (2012). Heterogeneity in business groups and the corporate diversification-firm performance relationship. Journal of Business Research, 65(3), 412420.

Gertner, R. H., Scharfstein, D. S., \& Stein, J. C. (1994). Internal versus external capital markets. Quarterly Journal of Economics, 109(4), 1211-1230.

Gomez, E. T., \& Jomo, K. S. (1999). Malaysia's political economy: Politics, patronage and profits. Selangor: Strategic Information and Research Development Centre.

Gopalan, R., Nanda, V., \& Seru, A. (2007). Affiliated firms and financial support: Evidence from Indian business groups. Journal of Financial Economics, 86(3), 759-795.

Granovetter, M. (1994). Business Groups. In: N. J. Smelser and R. Svedberg(eds.), The Handbook of Economic Sociology, New York: Princeton University Press.

Granovetter, M. (2005). The impact of social structure on economic outcomes. Journal of Economic Perspectives, 19(1), 33-50.

Guillen, M. F. (2000). Business groups in emerging economies: A resource-based view. Academy of Management Journal, 43(3), 362-380.

Hadley, E. (1970). Antitrust in Japan. Princeton: Princeton University Press.

Haunschild, P. R., \& Beckman, C. M. (1998). When do interlocks matter? Alternate sources of information and interlock influence. Administrative Science Quarterly,43(4), 815-844.

Holmes Jr, R. M., Kim, H., Wan, W. P., \& Holcomb, T. R. (2015, January). Business Group Research in Strategy and its Related Fields: A Review and Research Agenda. In Academy of Management Proceedings (Vol. 2015, No. 1, p. 17577). Academy of Management.

Joh, S. W. (2003). Corporate governance and firm profitability: evidence from Korea before the economic crisis. Journal of financial Economics, 68(2), 287-322.

Jones, Leroy P., \& I. Sakong (1980). Government Business and Entrepreneurship Development: the Korean Case; Cambridge: Council of East Asian Studies.

Kakani, R. K. (2000). Financial performance and diversification strategy of Indian business groups. Unpublished Ph.D. Dissertation presented to Indian Institute of Management, Calcutta.

Kali, R., \& Sarkar, J. (2005). Diversification, propping and monitoring: Business groups, firm performance and the Indian economic transition; Working Paper Series; Indira Gandhi Institute of Development Research.

Kedia, B. L., Mukherjee, D., \& Lahiri, S. (2006). Indian business groups: Evolution and transformation. Asia Pacific Journal of Management, 23(4), 559-577.

Keister, L. A. (1998). Engineering growth: Business group structure and firm performance in China's transition economy. American Journal of Sociology, 104(2), 404-440. 
Khandwalla, P. N. (2002). Effective organizational response by corporates to India's liberalization and globalization. Asia Pacific Journal of Management, 19(2), 423-448.

Khanna, T. (2000). Business groups and social welfare in emerging markets: Existing evidence and unanswered questions. European Economic Review, 44(4), 748-761.

Khanna, T., \& Palepu, K. (1997). Why focused strategies may be wrong for emerging markets. Harvard Business Review, 75, 41-54.

Khanna, T., \& Palepu, K. (1999a). Policy shocks, market intermediaries, and corporate strategy: The evolution of business groups in Chile and India. Journal of Economics \& Management Strategy, 8(2), 271-310.

Khanna, T., \& Palepu, K. (1999b). The right way to restructure conglomerates in emerging markets. Harvard Business Review, 77, 125-135.

Khanna, T., \& Palepu, K. (2000a). Is group affiliation profitable in emerging markets? An analysis of diversified Indian business groups. Journal of Finance, 55(2), 867-891.

Khanna, T., \& Palepu, K. (2000b). The future of business groups in emerging markets: Long-run evidence from Chile. Academy of Management Journal, 43(3), 268-285.

Khanna, T., \& Palepu, K. (2005). The evolution of concentrated ownership in India: broad patterns and a history of the Indian software industry. A history of corporate governance around the world: Family business groups to professional managers (pp. 283-324). University of Chicago Press.

Khanna, T., \& Rivkin, J. W. (2001). Estimating the performance effects of business groups in emerging markets. Strategic Management Journal, 22(1), 45-74.

Khanna, T., \& Yafeh, Y. (2005a). Business groups in emerging markets: Paragons or parasites? ECGI-Finance Working Paper, (92).

Khanna, T., \& Yafeh, Y. (2005b). Business groups and risk sharing around the world. Journal of Business, 78(1), 301-340.

Kieser, A., (1989). Organizational, institutional and societal evolution: Medieval craft guilds and the genesis of formal organizations. Administrative Science Quarterly, 34, 540-565

Kim, E. M. (1997). Big business, strong state: collusion and conflict in South Korean development, 1960-1990. SUNY Press.

Lang, L. \& Stulz, R. (1994). Tobin's q, corporate diversification and firm performance. Journal of Political Economy, 102(6), 1248-1280.

La Porta, R., Lopez-de-Silanes, F., \& Shleifer, A. (1999). Corporate ownership around the world. The journal of finance, 54(2), 471-517.

Leblebici, H., Salancik, G. R., Copay, A., \& King, T. (1991). Institutional change and the transformation of interorganizational fields: An organizational history of the US radio broadcasting industry. Administrative Science Quarterly, 36(3), 333-363.

Lee, K., Peng, M., \& Lee, K. (2001). Institutions and changing performance of corporate groups: The case of the chaebols in Korea. Unpublished Manuscript (Korea Institute of Finance).

Lee, K., Peng, M. W., \& Lee, K. (2008). From diversification premium to diversification discount during institutional transitions. Journal of World Business, 43(1), 47-65.

Leff, N. (1976). Capital markets in the less developed countries: The group principle. Money and Finance in Economic Growth and Development, 3, 97-126.

Leff, N. H. (1978). Industrial organization and entrepreneurship in the developing countries: The economic groups. Economic Development and Cultural Change,26(4), 661-675.

Lensink, R., \& Van der Molen, R. (2010). Does group affiliation increase firm value for diversified groups? New evidence from Indian companies. Journal of Empirical Finance, 17(3), 332344.

Lincoln, J. R., Gerlach, M. L., \& Takahashi, P. (1992). Keiretsu networks in the Japanese 
economy: A dyad analysis of intercorporate ties. American Sociological Review, 57(5), 561585.

Lins, K., \& Servaes, H. (1999). International evidence on the value of corporate diversification. Journal of Finance, 54(6), 2215-2239.

Lorenzoni, G., \& Baden-Fuller, C. (1995). Creating a strategic center to manage a web of partners. California Management Review, 37(3), 146-163.

Majumdar, S. K. (2004). The hidden hand and the license raj to an evaluation of the relationship between age and the growth of firms in India. Journal of Business Venturing, 19(1), 107125.

Oliver, C. (1992). The antecedents of deinstitutionalization. Organization Studies, 13(4), 563-588.

Peng, M.W. (2003). Institutional transitions and strategic choices. Academy of Management Review, 28(2), 275-296

Pettigrew, A. M. (1992). On studying managerial elites. Strategic Management Journal, 13(S2), 163-182.

Piramal, G. (1999). Business legends. Penguin Books India.

Poppo, L., \& Zenger, T. (2002). Do formal contracts and relational governance function as substitutes or complements? Strategic Management Journal, 23(8), 707-725.

Porta, R., Lopez-de-Silanes, F., \& Shleifer, A. (1999). Corporate ownership around the world. Journal of Finance, 54(2), 471-517.

Servaes, H. (1996). The value of diversification during the conglomerate merger wave. Journal ofFinance,51(4), 1201-1225.

Shin, H. \& Park, Y. (2003). Financing constraints and internal capital markets: Evidence from Korean chaebols. Journal of Corporate Finance, 5, 169-191.

Singhal, A., \& Tagore, A. (2002). Big industry before independence: 1860-1950 (No. 25, pp. 6169). Working Paper.

Stearns, L. B., \& Mizruchi, M. S. (1986). Broken-tie reconstitution and the functions of interorganizational interlocks: A reexamination. Administrative Science Quarterly, 31(4) 522-538.

Teece, D. J. (1981). Internal organization and economic performance: An empirical analysis of the profitability of principal firms. Journal of Industrial Economics, 30(2), 173-199.

Williamson, O. E. (1975). Markets and hierarchies: Analysis and Antitrust Implications, New York: The Free Press.

Williamson, O. E. (1981a). The economics of organization: The transaction cost approach. American Journal of Sociology, 87(3), 548-577.

Williamson, O. E. (1981b). The modern corporation: origins, evolution, attributes. Journal of Economic Literature, 19(4), 1537-1568

Williamson, O. E. (1985). The economic institutions of capitalism. New York: Simon and Schuster.

Windolf, P., \& Beyer, J. (1996). Co-operative capitalism: corporate networks in Germany and Britain. British Journal of Sociology, 47(2), 205-231.

Yiu, D., Bruton, G. D., \& Lu, Y. (2005). Understanding business group performance in an emerging economy: Acquiring resources and capabilities in order to prosper. Journal of Management Studies, 42(1), 183-206.

Yiu, D. W., Lu, Y., Bruton, G. D., \&Hoskisson, R. E. (2007). Business groups: An integrated model to focus future research. Journal of Management Studies, 44(8), 1551-1579.

Xavier, W. G., Bandeira-de-Mello, R., \& Marcon, R. (2014). Institutional environment and 
Business Groups' resilience in Brazil. Journal of Business Research, 67(5), 900-907.

Zattoni, A., Pedersen, T., \& Kumar, V. (2009). The performance of group-affiliated firms during institutional transition: A longitudinal study of Indian firms. Corporate Governance: An International Review, 17(4), 510-523. 